\title{
Application of Lignite Combustion Waste Slag Generated in Heating Plants as a Partial Replacement for Cement. Part II: Physical-Mechanical and Physical-Chemical Characterization of Mortar and Concrete
}

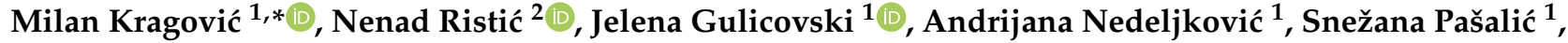 \\ Ivica Ristović ${ }^{3}$ and Marija Stojmenović ${ }^{1}(\mathbb{D})$ \\ 1 "Vinča" Institute of Nuclear Sciences, National Institute of the Republic of Serbia, University of Belgrade, \\ 11351 Belgrade, Serbia; rocenj@vinca.rs (J.G.); andrijana.nedeljkovic@vinca.rs (A.N.); \\ snezana.pasalic@vinca.rs (S.P.); mpusevac@vinca.rs (M.S.) \\ 2 Faculty of Civil Engineering and Architecture, University of Niš, 18106 Niš, Serbia; nenad.ristic@gaf.ni.ac.rs \\ 3 Faculty of Mining and Geology, University of Belgrade, 11000 Belgrade, Serbia; ivica.ristovic@rgf.bg.ac.rs \\ * Correspondence: m.kragovic@vinca.rs \\ check for
} updates

Citation: Kragović, M.; Ristić, N.; Gulicovski, J.; Nedeljković, A.; Pašalić, S.; Ristović, I.; Stojmenović, M. Application of Lignite Combustion Waste Slag Generated in Heating Plants as a Partial Replacement for Cement. Part II: Physical-Mechanical and Physical-Chemical Characterization of Mortar and Concrete. Minerals 2021, 11, 925. https://doi.org/ $10.3390 / \min 11090925$

Academic Editors: Carlito Tabelin, Chongchong Qi, Guichen Li, Hakan Basarir, Qiusong Chen and Yuantian Sun

Received: 17 June 2021

Accepted: 24 August 2021

Published: 27 August 2021

Publisher's Note: MDPI stays neutral with regard to jurisdictional claims in published maps and institutional affiliations.

Copyright: (c) 2021 by the authors. Licensee MDPI, Basel, Switzerland. This article is an open access article distributed under the terms and conditions of the Creative Commons Attribution (CC BY) license (https:/ / creativecommons.org/licenses/by/ $4.0 /)$.

\begin{abstract}
The presented study is a continuation of the research with the aim of finding a useful value of hazardous waste slag generated by the combustion of lignite in heating plants and its application in the construction industry. The different amounts of cement $(10 \%, 15 \%, 20 \%$ and $25 \%$ ) were replaced with waste slag and silica fumes in mortars and concrete production. Detailed physical-mechanical characterization was performed on the mortar and concrete samples according to standard procedures. Test results indicated that the replacement of cement with slag and silica fumes reduces the physical and mechanical properties of mortar and concrete, but cement composites retained the required structural properties. If $15-20 \%$ is considered an acceptable level of compressive strength decrease, then it can be concluded that waste slag can be implemented in practice and be used as a construction material, with cement replacement in the maximal amount of $20 \%(17.8 \%$ of slag and $2.2 \%$ of silica fumes). On hardened mortar samples with maximal possible cement replacement $(20 \%)$, physical-chemical characterizations were performed and included X-ray and infrared spectrophotometry, scanning electron microscopy, and thermal analysis. Results showed the absence of new phases and the presence of only those which were characteristic for starting samples, predominantly portlandite, quartz, calcite and calcium silicate-oxide.
\end{abstract}

Keywords: lignite combustion; waste slag; cement replacement; mortar and concrete production; physical-mechanical and physical-chemical characterization

\section{Introduction}

Coal is a solid fuel that has been used as a primary fossil fuel for centuries. The world's known coal reserves are much greater than those of gas and oil which means that it will be dominant in energy supply in the subsequent years [1-3]. Depending on the time of formation, coal can be classified as anthracite, bituminous coal, and lignite [4]. Lignite is a type of coal from the early stages of coalification whose properties are intermediate between peat and bituminous coal. Because of its low mining cost, easy access, high reactivity, and low price, the world's annual lignite production and consumption is approximately $1,000,000,000$ tons $[3,5,6]$.

However, besides its good properties, lignite also has some significant disadvantages such as calorific value, high-combustion waste content, the release of polluting gases $\left(\mathrm{SO}_{\mathrm{x}}\right.$, $\mathrm{CO}_{x}, \mathrm{P}_{x} \mathrm{O}_{y}$, etc.) which may cause serious environmental problems (the greenhouse effect, soil or water contamination, etc.) [3]. The non-combustible part of lignite mainly consists of moisture and ash, of which about $85-95 \%$ is fly ash and about $10 \%$ is slag [7]. Fly ash 
and slag are usually rich in different heavy metals and because of this, they can be harmful for the environment and human health, and consequently may be classified as hazardous waste [8]. The high amounts of produced and consumed lignite generate large quantities of combustion (hazardous) waste worldwide. Such significant quantities of hazardous waste undoubtedly have a vast negative impact on the environment, and because of that, it is particularly important to find a way for its safe storage and disposal. Finding the useful value of such generated waste as cement replacement in the construction industry is certainly a step in the right direction.

However, concerning the application of waste in the construction industry, previous research has largely been focused on finding the useful value of fly ash [9], blast furnace slag of different origins [10,11], or slag and ash from the metallurgical industry [12,13]. Additionally, there are some studies which described that the tailings materials generated in gold or copper mines may be used as construction materials, whereby the best results can be obtained after a tailings stabilization via suitable geo-polymerization [14,15]. At the same time, to our knowledge, the slag generated as waste in municipal heating plants due to lignite combustion, has not yet been sufficiently tested. This slag is very poorly described in the literature, and it is very difficult to find results related to finding its potential useful value. Additionally, it is important to emphasize the fact that for waste materials, constant research must be carried out. Very often, waste generated from different raw materials, origins (deposits, or lots), or treatments can have completely contrasting properties. For these reasons, each landfill must be monitored separately, and complete research must be carried out in order to find the potential useful value of such waste.

Accordingly, in order to solve environmental problems related to hazardous waste slag from lignite combustion, the potential use of waste slag generated in the heating plant in Valjevo, Serbia, as a replacement for cement in the production of mortar and concrete in the construction industry, was examined. Firstly, the detailed physical-chemical and physical-mechanical characterizations of slag were performed [16]. In this paper, Nedeljković et al. [16] clearly showed the properties of waste slag and gave explanations and suggestions on how waste slag, which in raw form did not meet the prescribed conditions in terms of its characteristics, could be used as a replacement for cement. Namely, the results showed that the lack of slag in terms of the content of $\mathrm{SiO}_{2}, \mathrm{Al}_{2} \mathrm{O}_{3}$, $\mathrm{Fe}_{2} \mathrm{O}_{3}$, and unburned carbon, and the loss of ignition, may be overcome by the thermal treatment of the slag prior to use, up to $650{ }^{\circ} \mathrm{C}$. Results also showed that other physicalchemical characteristics of slag (crystal, structural, and textural properties) completely satisfied the criteria prescribed by the standard EN 450-1:2012. The physical-mechanical testing showed that slag does not possess pozzolanic activity, and this was solved by mixing the slag with silica fumess in minimal amounts (slag/silica fumes $=88 \% / 12 \%$ ). The maximal possible cement replacement was $20 \%$ with $17.8 \%$ of slag and $2.2 \%$ of silica fumes. The leaching tests were also performed in accordance with the standard EN 12457-2 on the mortar with $20 \%$ of cement replacement. The leaching was carried out on crushed hardened mortar with water by mixing the mixture for $24 \mathrm{~h}$, with the liquid/solid ratio of $10 \mathrm{dm}^{3} / \mathrm{kg}$. The results showed the negligible release of heavy metals whose values were much lower in comparison with values prescribed by the "Rulebook on permitted quantities of hazardous and harmful materials in agricultural land and water for irrigation and methods for testing", applicable in Serbia which meant that the obtained mortar met all the required health and environmental criteria.

This paper is a continuation of that research. After the characterization of waste slag and finding ways for its potential application in the construction industry, it was important to investigate mortars and concretes in which the partial replacement of cement with waste slag was carried out. For that purpose, the optimal conditions for the practical application in mortar and concrete production are defined. Tests related to the use of waste slag as a partial replacement for cement in the production of mortars and concrete are performed in accordance with certain standards, and the detailed physical-mechanical and physical-chemical characterization of mortar and concrete is carried out. 


\section{Materials and Methods}

\subsection{Sampling}

The waste slag generated by the combustion of lignite was sampled from the landfill of the heating plant located in Valjevo, Serbia. The sampling was performed as it is described elsewhere [16]. Since in the plant there is no planned waste disposal, in order to get a more realistic picture in terms of the quality of waste material, samples were taken by the square method from different places so that material of different ages was included. After sampling, the samples were mixed, homogenized and the required amount for analysis was taken by quartering.

Portland cement (CEM I 42.5R) was bought from the company CRH Popovac, Serbia. Silica fumes were bought from the company "Sika". The physical-chemical, chemical and mineralogical composition of the used cement, slag and silica fumes are given in Table 1.

Table 1. The physical-chemical, chemical and mineralogical properties of the used cement, slag and silica fumes [16].

\begin{tabular}{cccc}
\hline Properties/Content & Cement & Slag & Silica Fume \\
\hline$\rho, \mathrm{g} / \mathrm{cm}^{3}$ & 3.15 & 2.24 & 2.21 \\
$\mathrm{~S}_{\mathrm{BET}}, \mathrm{m}^{2} / \mathrm{g}$ & 1.22 & 25.00 & 28.14 \\
$\mathrm{SiO}_{2}, \%$ & 21.62 & 21.20 & 93.60 \\
$\mathrm{Fe}_{2} \mathrm{O}_{3}, \%$ & 2.60 & 10.81 & 0.21 \\
$\mathrm{Al}_{2} \mathrm{O}_{3}, \%$ & 7.00 & 15.70 & 0.27 \\
$\mathrm{CaO}, \%$ & 60.16 & 6.32 & 0.05 \\
$\mathrm{MgO}, \%$ & 2.34 & 2.50 & 0.05 \\
$\mathrm{SO}{ }_{3}, \%$ & 2.55 & 1.78 & 0.80 \\
$\mathrm{Na}_{2} \mathrm{O}, \%$ & 0.33 & 2.67 & 0.23 \\
$\mathrm{~K}_{2} \mathrm{O}, \%$ & 0.66 & 0.63 & 0.50 \\
$\mathrm{P}_{2} \mathrm{O}_{5}, \%$ & - & 0.036 & - \\
$\mathrm{LOI}, \%$ & 2.68 & 37.45 & 2.40 \\
& brownmillerite, calcium silicate & quartz, olivine, & \\
Mineral composition & oxide, calcite, larnite, & magnetite, pyrite, & quartz \\
& magnesium silicate, calcium & tridymite, feldspars & \\
\hline
\end{tabular}

For making mortar, fine river sand (fraction $0 / 2 \mathrm{~mm}$ ) was used. Specific gravity and water absorption of the used sand were $2610 \mathrm{~kg} / \mathrm{m}^{3}$ and $1.52 \%$, respectively. For making concrete, a crushed gabbro was used as the coarse aggregates (fractions $4 / 8 \mathrm{~mm}$ and $8 / 16 \mathrm{~mm}$ ) which had a specific gravity of $2890 \mathrm{~kg} / \mathrm{m}^{3}$ and a water absorption of $0.58 \%$. River sand with a nominal maximum size of $4 \mathrm{~mm}$ (fraction $0 / 4 \mathrm{~mm}$ ), the specific gravity of $2620 \mathrm{~kg} / \mathrm{m}^{3}$, and water absorption of $1.42 \%$ was used as the fine aggregates.

\subsection{Concrete and Mortar Preparation}

Preparation of mortar mixtures and production and curing of specimens for testing the physical-mechanical characteristics of hardened mortar was performed according to the standard EN 191-1. A total of 5 different mortar mixes were made: reference mixtures (E-M) and four mixtures (PM-10, PM-15, PM-20, and PM-25) in which cement was replaced with $10 \%, 15 \%, 20 \%$, and $25 \%$ of slag and silica fumes regarding mass (whereby slag participated with $88 \%$, and silica fumes with $12 \%$ ). The mass ratio between the quantity of binder and sand in all mixtures was 1:3, while the mass ratio between the water and binder was 1:2. Superplasticizer was used to improve the workability of the mortar mixtures, and the same amount was added to all mixtures. Table 2 shows quantities of material for making one series of mortar specimens (3 prisms with dimensions $40 \mathrm{~mm} \times 40 \mathrm{~mm} \times 160 \mathrm{~mm}$ ) in the laboratory mixer "Hobart N-50". 
Table 2. Mix proportion of mortar for one series of samples.

\begin{tabular}{|c|c|c|c|c|c|}
\hline Component & E-M & P10-M & P15-M & P20-M & P25-M \\
\hline Cement $\left[\mathrm{g}\left(\mathrm{cm}^{3}\right)\right]$ & $450.00(142.86)$ & $402.34(127.73)$ & $378.73(120.23)$ & $355.27(112.78)$ & $331.96(105.38)$ \\
\hline Slag $\left[\mathrm{g}\left(\mathrm{cm}^{3}\right)\right]$ & - & $39.79(17.76)$ & $59.48(26.55)$ & $79.05(35.29)$ & $98.48(43.96)$ \\
\hline Silica fumes $\left[\mathrm{g}\left(\mathrm{cm}^{3}\right)\right]$ & - & $4.90(2.23)$ & $7.36(3.33)$ & $9.77(4.42)$ & $12.18(5.51)$ \\
\hline River sand $0 / 2 \mathrm{~mm}\left[\mathrm{~g}\left(\mathrm{~cm}^{3}\right)\right]$ & $1350.00(517.24)$ & $1341.14(513.85)$ & $1336.70(512.15)$ & $1332.26(510.44)$ & $1327.83(508.75)$ \\
\hline Water $[\mathrm{g}]$ & $225.00(225.00)$ & $223.52(223.52)$ & $222.78(222.78)$ & $222.04(222.04)$ & $221.30(221.30)$ \\
\hline Superplasticizer $\left[\mathrm{g}\left(\mathrm{cm}^{3}\right)\right]$ & $3.60(3.30)$ & $3.58(3.28)$ & $3.56(3.27)$ & $3.55(3.26)$ & $3.54(3.25)$ \\
\hline SUM $\left[\mathrm{g}\left(\mathrm{cm}^{3}\right)\right]$ & $2028.60(888.40)$ & $2015.29(888.37)$ & $2008.62(888.24)$ & $2001.94(888.24)$ & $1995.28(888.16)$ \\
\hline
\end{tabular}

Preparation of concrete mixtures, production and curing of specimens for testing of compressive strength of concrete was performed according to the standard EN 12390-2. A total of 5 different mixtures were used, in which cement was replaced with slag and silica fumes in the same mass percentage as was the case in making the mortar mixtures. All mixtures were made with the same water-binder ratio $\mathrm{w} / \mathrm{b}=0.486$ and the same mass ratio of aggregate and binder $\mathrm{m}_{\mathrm{agg}} / \mathrm{m}_{\mathrm{b}}=5.003$. Superplasticizer was used for the improvement of the consistency of fresh concrete and the same quantity was added to all concrete mixtures. Mix proportions of concrete mixtures for $1 \mathrm{~m}^{3}$ of concrete are given in Table 3.

Table 3. Mix proportion of concrete mixtures for $1 \mathrm{~m}^{3}$ of concrete.

\begin{tabular}{|c|c|c|c|c|c|}
\hline Component & E-C & P10-C & P15-C & P20-C & P25-C \\
\hline Cement $\left[\mathrm{kg}\left(\mathrm{m}^{3}\right)\right]$ & $375.00(0.119)$ & $336.32(0.107)$ & $316.78(0.101)$ & $297.32(0.094)$ & $277.67(0.088)$ \\
\hline Slag $[\mathrm{kg}]$ & - & $33.16(0.015)$ & $49.65(0.022)$ & $66.08(0.029)$ & $82.34(0.037)$ \\
\hline Silica fumes $\left[\mathrm{kg}\left(\mathrm{m}^{3}\right)\right]$ & - & $4.15(0.002)$ & $6.21(0.003)$ & $8.26(0.004)$ & $10.30(0.005)$ \\
\hline River sand $0 / 4 \mathrm{~mm}\left[\mathrm{~kg}\left(\mathrm{~m}^{3}\right)\right]$ & $752.00(0.287)$ & $748.26(0.286)$ & $746.77(0.285)$ & $745.29(0.284)$ & $743.08(0.284)$ \\
\hline Crushed aggr. $(4 / 8 \mathrm{~mm})\left[\mathrm{kg}\left(\mathrm{m}^{3}\right)\right]$ & $432.00(0.149)$ & $429.85(0.149)$ & $429.00(0.148)$ & $428.15(0.148)$ & $426.88(0.148)$ \\
\hline Crushed aggr. $(8 / 16 \mathrm{~mm})\left[\mathrm{kg}\left(\mathrm{m}^{3}\right)\right]$ & $692.00(0.239)$ & $688.56(0.238)$ & $687.19(0.238)$ & $685.83(0.237)$ & $683.79(0.237)$ \\
\hline Water $\left[\mathrm{kg}\left(\mathrm{m}^{3}\right)\right]$ & $182.25(0.182)$ & $181.34(0.181)$ & $180.98(0.181)$ & $180.62(0.181)$ & $180.09(0.180)$ \\
\hline Superplasticizer $\left[\mathrm{kg}\left(\mathrm{m}^{3}\right)\right]$ & $3.75(0.003)$ & $3.73(0.003)$ & $3.72(0.003)$ & $3.72(0.003)$ & $3.71(0.003)$ \\
\hline SUM & $2437(0.981)$ & $2425.37(0.981)$ & $2420.31(0.981)$ & $2415.26(0.981)$ & $2407.86(0.981)$ \\
\hline Assumed air content & $\sim 2 \%$ & $\sim 2 \%$ & $\sim 2 \%$ & $\sim 2 \%$ & $\sim 2 \%$ \\
\hline Component & E-C & P10-C & P15-C & P20-C & P25-C \\
\hline Cement $\left[\mathrm{kg}\left(\mathrm{m}^{3}\right)\right]$ & $375.00(0.119)$ & $336.32(0.107)$ & $316.78(0.101)$ & $297.32(0.094)$ & $277.67(0.088)$ \\
\hline Slag $[\mathrm{kg}]$ & - & $33.16(0.015)$ & $49.65(0.022)$ & $66.08(0.029)$ & $82.34(0.037)$ \\
\hline Silica fumes $\left[\mathrm{kg}\left(\mathrm{m}^{3}\right)\right]$ & - & $4.15(0.002)$ & $6.21(0.003)$ & $8.26(0.004)$ & $10.30(0.005)$ \\
\hline River sand $0 / 4 \mathrm{~mm}\left[\mathrm{~kg}\left(\mathrm{~m}^{3}\right)\right]$ & $752.00(0.287)$ & $748.26(0.286)$ & $746.77(0.285)$ & $745.29(0.284)$ & $743.08(0.284)$ \\
\hline Crushed aggr. $(4 / 8 \mathrm{~mm})\left[\mathrm{kg}\left(\mathrm{m}^{3}\right)\right]$ & $432.00(0.149)$ & $429.85(0.149)$ & $429.00(0.148)$ & $428.15(0.148)$ & $426.88(0.148)$ \\
\hline Crushed aggr. $(8 / 16 \mathrm{~mm})\left[\mathrm{kg}\left(\mathrm{m}^{3}\right)\right]$ & $692.00(0.239)$ & $688.56(0.238)$ & $687.19(0.238)$ & $685.83(0.237)$ & $683.79(0.237)$ \\
\hline Water $\left[\mathrm{kg}\left(\mathrm{m}^{3}\right)\right]$ & $182.25(0.182)$ & $181.34(0.181)$ & $180.98(0.181)$ & $180.62(0.181)$ & $180.09(0.180)$ \\
\hline Superplasticizer $\left[\mathrm{kg}\left(\mathrm{m}^{3}\right)\right]$ & $3.75(0.003)$ & $3.73(0.003)$ & $3.72(0.003)$ & $3.72(0.003)$ & $3.71(0.003)$ \\
\hline SUM & $2437(0.981)$ & $2425.37(0.981)$ & $2420.31(0.981)$ & $2415.26(0.981)$ & $2407.86(0.981)$ \\
\hline Assumed aer content & $\sim 2 \%$ & $\sim 2 \%$ & $\sim 2 \%$ & $\sim 2 \%$ & $\sim 2 \%$ \\
\hline
\end{tabular}

\subsection{Characterization of Mortar and Concrete Samples}

\subsubsection{Tests on Mortar Samples}

Consistency was determined by the flow table in accordance with the standard EN 1015-3. For the testing, a metal conical mold was used, with a lower base diameter of $100 \mathrm{~mm}$. The mean value of the mortar slump in two orthogonal directions on the flow table represented the test result.

The bulk density of fresh mortar was determined according to standard EN 1015-3, in a $1 \mathrm{dm}^{3}$ cylindrical metal vessel with $125 \mathrm{~mm}$ diameter. 
The bulk density of hardened mortar was determined in accordance with standard EN 1015-10, on the specimens used for testing of mechanical strengths, e.g., on the prisms with dimensions $40 \mathrm{~mm} \times 40 \mathrm{~mm} \times 160 \mathrm{~mm}$.

Flexural strength was determined in accordance with standards EN 196-1, EN 1015-11 and was tested on the prisms with dimensions $40 \mathrm{~mm} \times 40 \mathrm{~mm} \times 160 \mathrm{~mm}$. The tests were conducted on the hydraulic press UTCM-6710 (Utest, Ankara, Turkey) with a measuring range of $0-10 \mathrm{kN}$ of the flexural force and accuracy class $0.5 \%$. Compressive strength was determined according to standards EN 196-1 and EN 1015-11 and was tested on the halves of the prisms obtained after testing flexural strength. The test was conducted on the hydraulic press UTEST UTCM-6710 with a measuring range of 0 to $250 \mathrm{kN}$ of the compressive force and accuracy class $0.5 \%$. Water absorption (determination of water absorption at atmospheric pressure) was determined according to EN 13755 and was conducted on the prisms with dimensions $40 \mathrm{~mm} \times 40 \mathrm{~mm} \times 160 \mathrm{~mm}$. Prisms were firstly dried at the temperature of $70 \pm 5{ }^{\circ} \mathrm{C}$ to the constant mass, and then were saturated in water. The percentage difference of masses of a saturated and a dry sample, and the mass of the dry sample represents the water absorption at atmospheric pressure.

Water absorption (determination of water absorption coefficient due to capillary action of hardened mortar) was performed according to standard EN 1015-18 and was conducted on the halves of the prisms having dimensions $40 \mathrm{~mm} \times 40 \mathrm{~mm} \times 160 \mathrm{~mm}$. Prisms were firstly dried at a temperature of $60 \pm 5{ }^{\circ} \mathrm{C}$ to the constant mass $\left(\mathrm{M}_{0}\right)$. Then the surface of the prism failure was set on the linear supports in a deep vessel, where water was poured so that the prism was immersed by 5 to $10 \mathrm{~mm}$. Prior to the immersion, the mass of the dry sample was measured, and after the immersion, the mass of the sample was measured after $10 \mathrm{~min}\left(\mathrm{M}_{1}\right)$, $90 \mathrm{~min}\left(\mathrm{M}_{2}\right)$ and $24 \mathrm{~h}\left(\mathrm{M}_{3}\right)$. Water absorption coefficient due to capillary action was calculated according to the following formulas:

$$
\begin{gathered}
\text { for coating mortars : } C=0.1\left(\mathrm{M}_{2}-\mathrm{M}_{1}\right)\left[\mathrm{kg} / \mathrm{m}^{2} \mathrm{~min}^{-0.5}\right] \\
\text { for repairing mortars : } \mathrm{C}=0.625\left(\mathrm{M}_{3}-\mathrm{M}_{0}\right)\left[\mathrm{kg} / \mathrm{m}^{2}\right]
\end{gathered}
$$

Drying shrinkage was determined in accordance with standard SRPS B.C8.029:1979 (ASTM C 596) on mortar prisms and was performed on the samples having dimensions $40 \mathrm{~mm} \times 40 \mathrm{~mm} \times 160 \mathrm{~mm}$ with reference marks at their ends allowing for the monitoring of variation in length. After making mortar, mortar prisms were cured for $24 \mathrm{~h}$ in a mold in a water bath, after which they are removed from the mold and cured in water for the next $48 \mathrm{~h}$. Baseline reading was conducted $72 \mathrm{~h}$ after making the prisms, and then the readings were performed after 4, 7, 14, 21 and 28 days. The difference in reading represented a variation in the length of the tested sample, while the shrinkage of cement mortar was expressed as a ratio of variation in length and the initial length of the specimen at the start of testing. The difference in readings represented the variation in length of the tested sample, while shrinkage of the cement mortar was expressed as the ratio of length variation and the initial length of the sample at the start of testing. Mortar shrinkage $\varepsilon_{\mathrm{sm}, \mathrm{i}}$ was calculated according to the following equation:

$$
\varepsilon_{\mathrm{sm}, \mathrm{i}}=\frac{\Delta \mathrm{l}_{\mathrm{sm}}(\mathrm{t})}{1_{\mathrm{sm}}}[\mathrm{mm} / \mathrm{m}]
$$

where $\Delta \mathrm{l}_{\mathrm{sm}}(\mathrm{t})$ was the difference of the sample length at the moment that $\mathrm{t}$ and the baseline reading $\mathrm{t}=72 \mathrm{~h}$ in $\mathrm{mm} ; 1_{\mathrm{sm}}$ was the length of the mortar prism expressed in $\mathrm{m}$; and $\varepsilon_{\mathrm{sm}, \mathrm{i}}$ was the shrinkage of the mortar prism expressed in $\mathrm{mm} / \mathrm{m}$.

Adhesion (determination of adhesive strength of hardened rendering and plastering mortars on substrates) was determined according to standard EN 1015-12. A layer of mortar $10 \pm 1 \mathrm{~mm}$ was applied to the concrete substrate. Mortar and concrete surfaces were cut to $2 \mathrm{~mm}$ of height using the cylindrical drill having $50 \mathrm{~mm}$ diameter. Afterward, a steel dolly $50 \mathrm{~mm}$ in diameter was glued to the mortar using epoxy glue and the dolly 
was pulled off using the pull-off tester. The pull-off failure force was registered, as well as the location where the failure occurred. The adhesive strength of mortar to a concrete substrate was calculated according to the following formula:

$$
\mathrm{f}_{\mathrm{u}}=\frac{\mathrm{F}}{\mathrm{A}}
$$

where $\mathrm{F}$ was the failure force at pull-off and A was the surface area of the dolly.

\subsubsection{Tests of Physical-mechanical Properties of Concrete Samples}

Consistency-slump test was performed in accordance with standard EN 12350-2 and was determined using the Abrams cone slump method.

The density of fresh concrete was determined according to standard EN 12350-6, in a metal, cylindrical vessel with a capacity of $8 \mathrm{dm}^{3}$.

Air content in fresh concrete was determined according to standard EN 12350-7 by using the pressure method. For testing, an apparatus was used which consisted of a metal cylindrical vessel with a capacity of $8 \mathrm{dm}^{3}$ and a special lid with a pump and manometer.

The density of hardened concrete (water-saturated) was determined according to standard EN 12390-7 on the samples shaped like cubes with a side length of $150 \mathrm{~mm}$.

Flexural strength was determined in accordance with standard EN 12390-5 and testing was conducted on the prisms $400 \mathrm{~mm}$ in length, with a square cross-section sides of $100 \mathrm{~mm}$. A digital hydraulic press "UTC-5600" (Utest, Ankara, Turkey) was used for the testing. A special tool was used for the testing permitting the loading of the sample by a bending force at two thirds of the span. Compressive strength was determined according to standard EN 12390-3 on the samples shaped like cubes with a side length of $150 \mathrm{~mm}$. For the testing, digital, hydraulic press "UTC-5740" (Utest, Ankara, Turkey) with measuring range $0-3000 \mathrm{kN}$ and an accuracy class of $0.5 \%$ was used. The press was powered by servo-controlled hydraulic controller "UTC-4860" (Utest, Ankara, Turkey) and appropriate computer software. The test was conducted at the concrete age of 2, 7, 28, and 90 days.

\subsubsection{Physical-chemical Characterization of Hardened Mortar Samples}

The physical-chemical characterization was performed on hardened mortar samples with maximal possible cement replacement (20\%) (P-20M) and included X-Ray-Structural Diffraction Analysis (XRD), infrared spectroscopy (FTIR), field emission scanning electron microscopic analysis (FESEM), and thermal analysis.

The structural properties and the composition of the crystal phase of the hardened mortar samples were determined by the XRD. For analysis, a PW-1710 X-ray diffractometer (Philips, Amsterdam, Netherlands) with a scintillation counter and curved graphite monochromator was used. The measuring was performed at room temperature at $0.02^{\circ} / \mathrm{s}$, in the range of $4-65^{\circ} 2 \theta$. The voltage of $40 \mathrm{kV}$ and a current of $30 \mathrm{~mA}$ were used, while $1^{\circ}$ and $0.1 \mathrm{~mm}$ slits were used to direct the primary and diffracted beams.

The Thermo Scientific "Nicolet iS50" instrument (Thermo Fisher, Waltham, MA, USA) was used for infrared spectroscopic analyses (FTIR) of hardened mortar samples. Investigations were performed in the transmission mode. As background, the spectrum of the $\mathrm{KBr}$ was used. The wavelength range was $400-4000 \mathrm{~cm}^{-1}$, while the resolution and number of scans were $2 \mathrm{~cm}^{-1}$ and 64, respectively. Two corrections: baseline automatic correction and suppression of the atmosphere were used after recording the spectra.

The field emission scanning electron microscopy and instrument TESCAN Mira3 XMU at $20 \mathrm{kV}$ (Tescan, Brno-Kohoutovice, Czech Republic) was used for the investigation of the morphological and microstructural properties of the hardened mortar sample prepared under the procedure described in Table 2. Prior to analysis, the samples were pre-coated with a several nanometers-thick gold layer, using sputter coater Polaron SC503 Fision Instrument (Quorum Technologies Ltd., Lewes, UK).

Simultaneously, non-isothermal thermogravimetric analysis (TGA) and differential thermal analysis (DTA) of the hardened mortar samples was performed on a Setaram 
Setsys Evolution 1750 instrument (Setaram, Lion, France). Measuring was performed in the temperature range from 25 to $1000{ }^{\circ} \mathrm{C}$ with a heating rate of $10 \mathrm{~min}^{-1}$ in an air atmosphere, with a flow of $16 \mathrm{~cm}^{3} / \mathrm{min}$. The mass of the sample was $15 \mathrm{mg}$.

\section{Results and Discussion}

\subsection{Physical-Mechanical Characterization of Mortar and Concrete}

Results of the physical-mechanical characterization of samples are given in Tables 4 and 5 and Figures 1-6.

Table 4. Physical properties of fresh and hardened mortar.

\begin{tabular}{|c|c|c|c|c|c|c|}
\hline Parameter & Unit & E-M & P10-M & P15-M & P20-M & P25-M \\
\hline Consistency: by flow table & $\mathrm{mm}$ & $205 \pm 7.9$ & $187 \pm 7.2$ & $169 \pm 7.5$ & $152 \pm 6.4$ & $136 \pm 6.0$ \\
\hline Bulk density of fresh mortar & $\mathrm{kg} / \mathrm{m}^{3}$ & $2248 \pm 12.3$ & $2215 \pm 10.4$ & $2186 \pm 12.0$ & $2158 \pm 9.1$ & $2126 \pm 10.9$ \\
\hline \multirow{2}{*}{$\begin{array}{l}\text { Dry bulk density of hardened mortar } \\
\text { Water absorption (water absorption at } \\
\text { atmospheric pressure) }\end{array}$} & $\mathrm{kg} / \mathrm{m}^{3}$ & $2176 \pm 11.5$ & $2132 \pm 12.4$ & $2073 \pm 12.0$ & $2055 \pm 9.7$ & $2031 \pm 10.2$ \\
\hline & $\%(\mathrm{~m} / \mathrm{m})$ & $7.1 \pm 0.19$ & $7.5 \pm 0.15$ & $8.2 \pm 0.17$ & $8.1 \pm 0.14$ & $7.9 \pm 0.18$ \\
\hline $\begin{array}{l}\text { Water absorption (coefficient due } \\
\text { to capillary } \\
\text { action of hardened mortar): for mortars } \\
\text { other than renovation mortars }\end{array}$ & $\begin{array}{c}\mathrm{m}^{2} \times \\
\min ^{-0.5}\end{array}$ & $0.25 \pm 0.016$ & $0.21 \pm 0.018$ & $0.23 \pm 0.014$ & $0.23 \pm 0.020$ & $0.19 \pm 0.015$ \\
\hline $\begin{array}{l}\text { Water absorption (coefficient due } \\
\text { to capillary } \\
\text { action of hardened mortar): for } \\
\text { renovation mortars }\end{array}$ & $\mathrm{kg} / \mathrm{m}^{2}$ & $7.65 \pm 0.104$ & $5.19 \pm 0.122$ & $5.88 \pm 0.134$ & $5.67 \pm 0.115$ & $5.11 \pm 0.128$ \\
\hline
\end{tabular}

Table 5. Physical properties of fresh and hardened concrete.

\begin{tabular}{ccccccc}
\hline Parameter & Unit & E-C & P10-C & P15-C & P20-C & P25-C \\
\hline Consistency: slump test & $\mathrm{mm}$ & $240 \pm 12.3$ & $180 \pm 11.6$ & $140 \pm 10.4$ & $90 \pm 8.2$ & $20 \pm 6.5$ \\
Air content in fresh concrete & $\%$ & $2.5 \pm 0.25$ & $3.4 \pm 0.32$ & $4.1 \pm 0.34$ & $5.0 \pm 0.33$ & $5.6 \pm 0.35$ \\
$\quad$ Density of fresh concrete & $\mathrm{kg} / \mathrm{m}^{3}$ & $2473 \pm 17.7$ & $2432 \pm 16.2$ & $2369 \pm 15.5$ & $2349 \pm 16.0$ & $2341 \pm 14.3$ \\
$\begin{array}{c}\text { Density of hardened concrete } \\
\text { (water-saturated }\end{array}$ & $\mathrm{kg} / \mathrm{m}^{3}$ & $2465 \pm 16.9$ & $2422 \pm 17.5$ & $2360 \pm 14.7$ & $2338 \pm 15.4$ & $2331 \pm 15.0$ \\
\hline
\end{tabular}

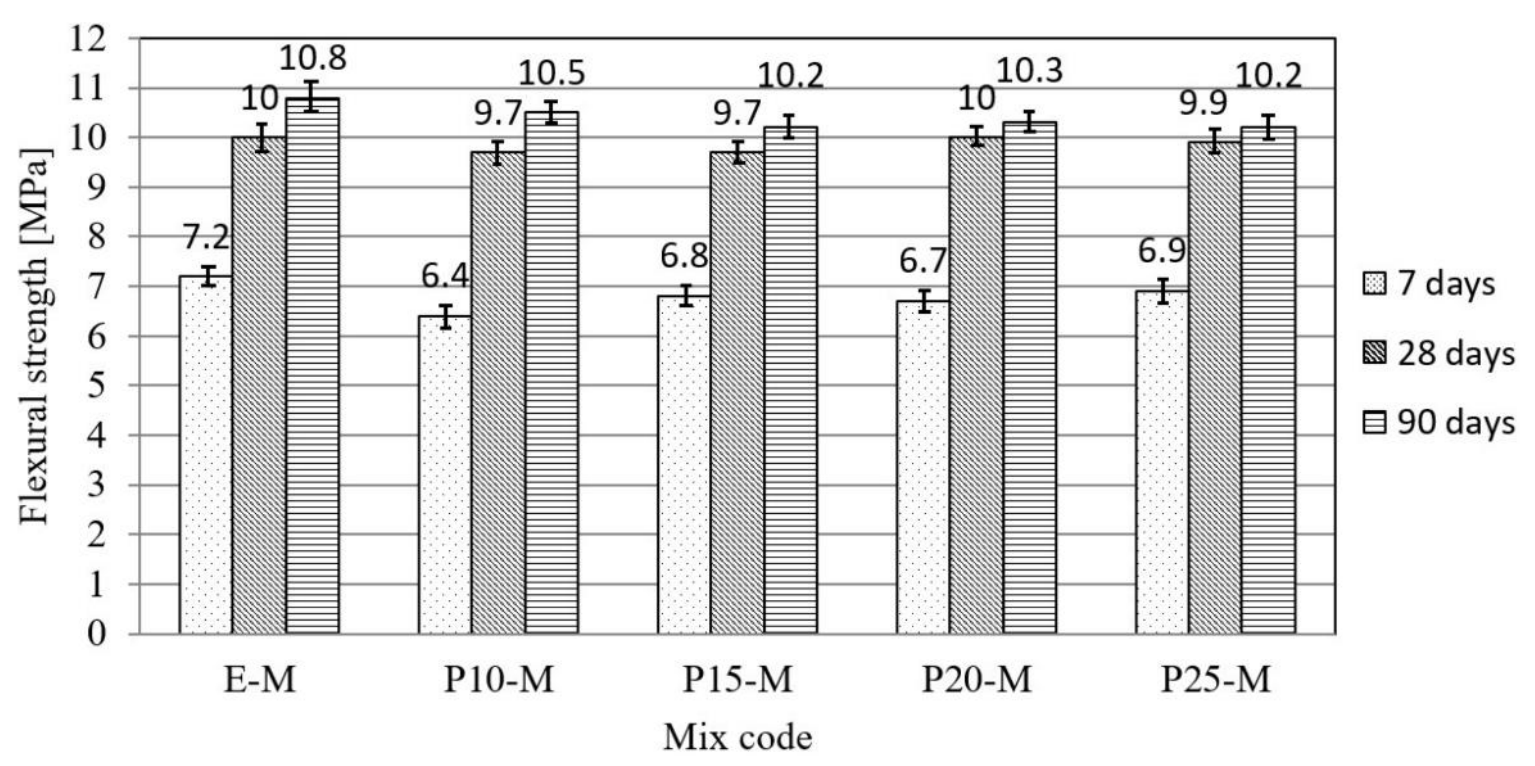

Figure 1. Flexural strength of mortar mixtures. 


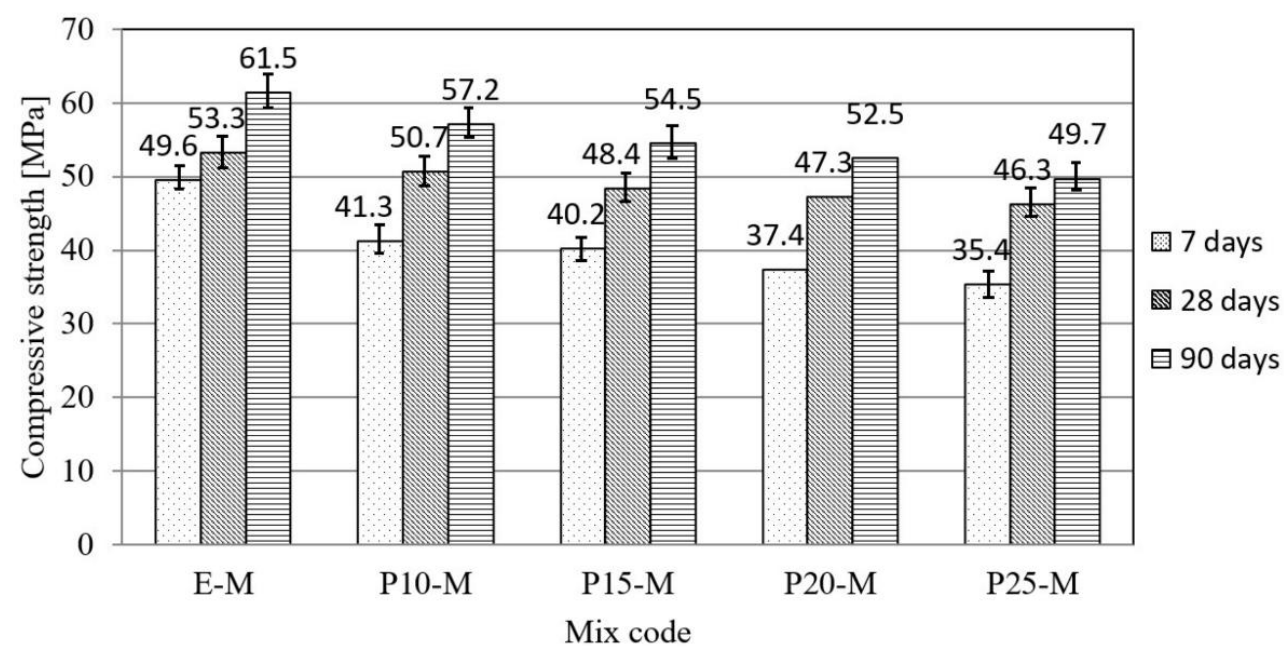

Figure 2. Compressive strength of mortar mixtures.

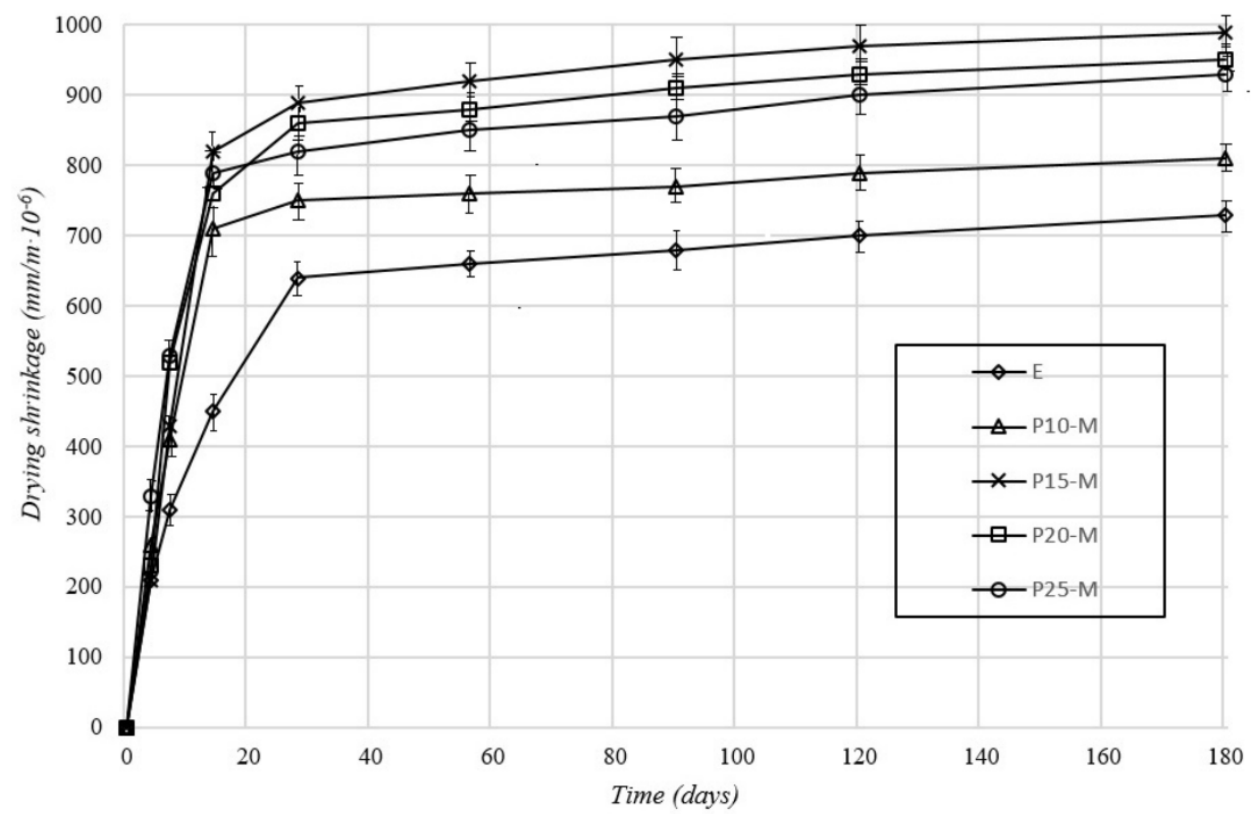

Figure 3. Drying shrinkage development of mortar mixtures.

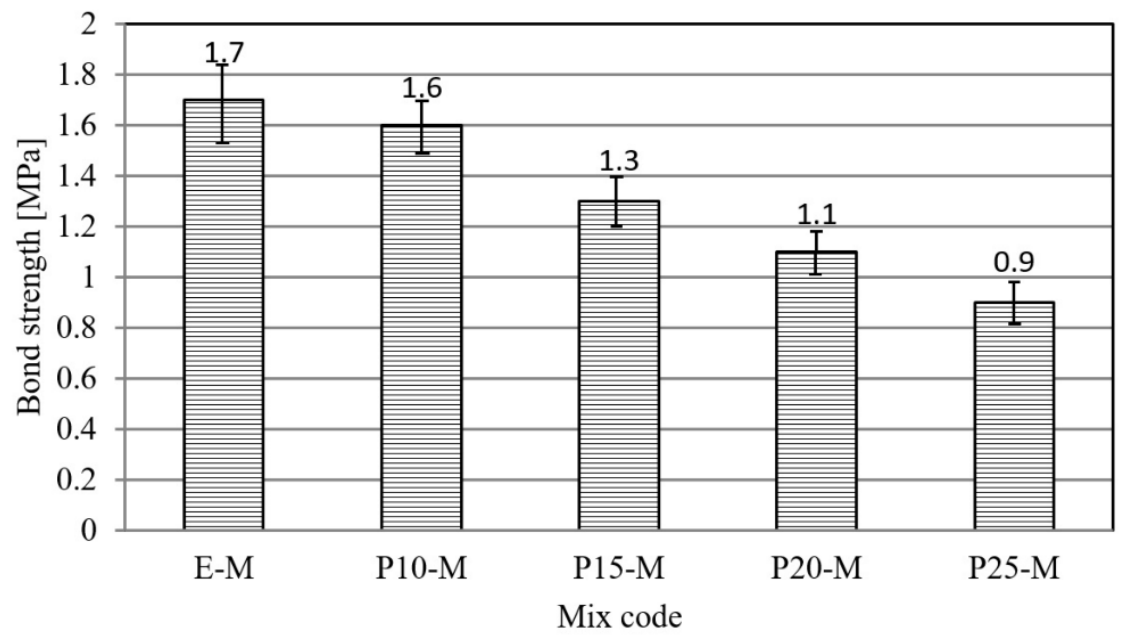

Figure 4. Adhesion between mortar and a concrete substrate. 


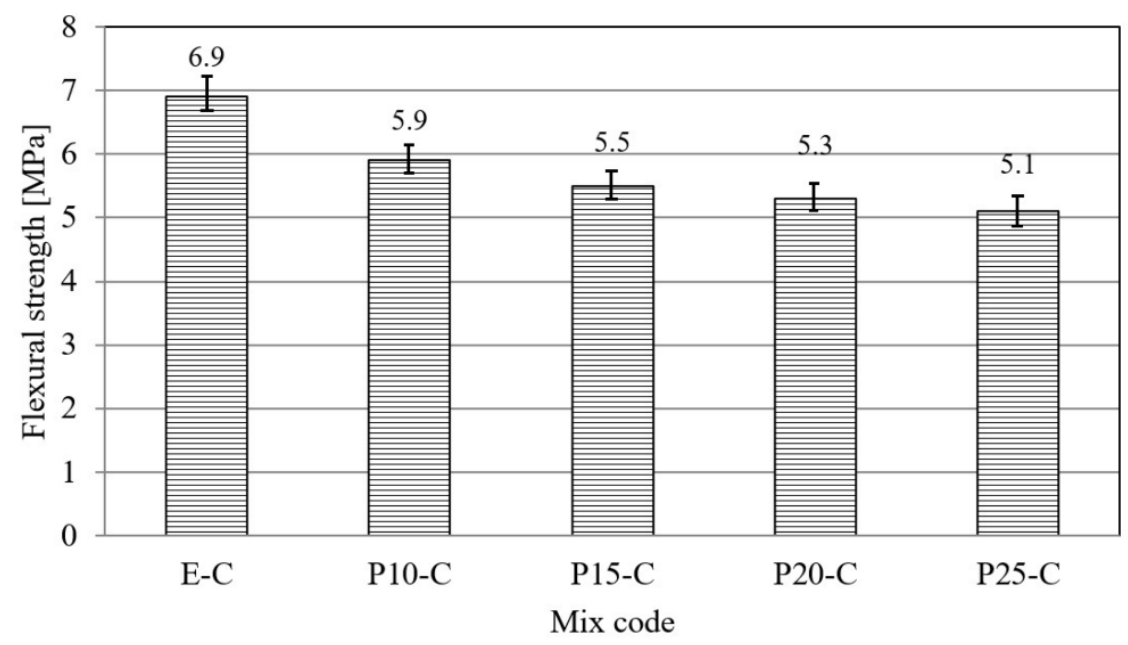

Figure 5. Flexural strength of concrete mixtures (28 days).

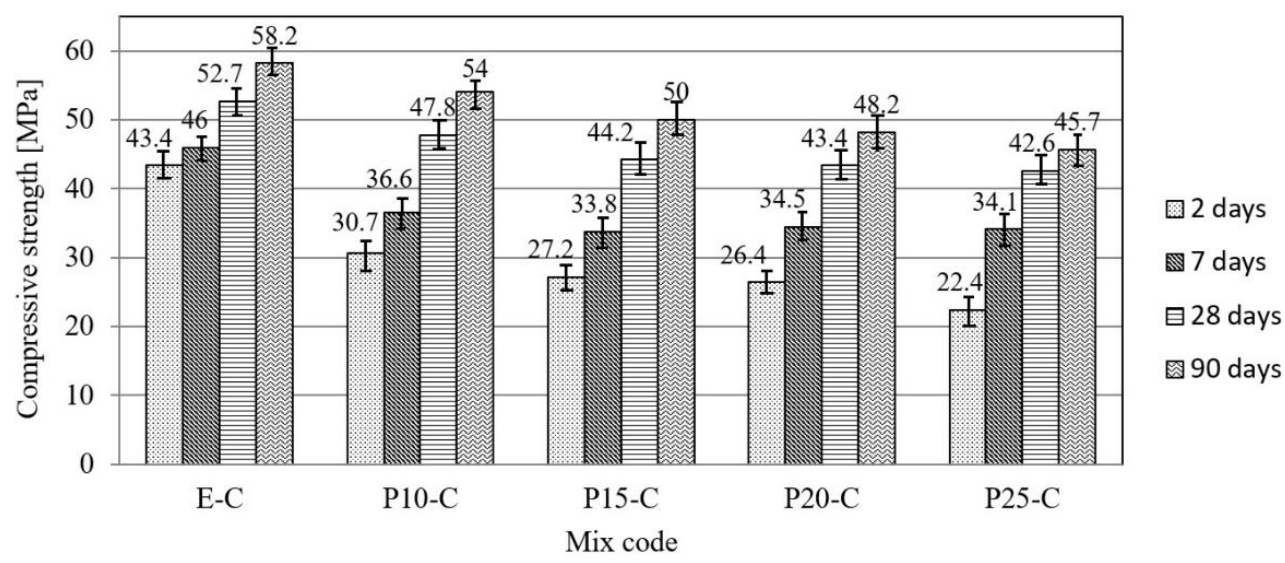

Figure 6. Compressive strength of concrete mixtures.

When testing the consistency of mortar, the slump of the mortar on a shaking table decreases with the increase in the percentage of cement replaced with slag and silica fumes. The reason is the increased water requirement of slag, which reduces the amount of free water in the mortar mixture, and thus its plasticity. By increasing the content of waste material, the bulk density of mortar in the fresh and hardened states decreases. Possible reasons for such trend were the lower specific mass of slag relative to cement, the increased porosity of the mortar due to a decrease in plasticity, as well as the lower amount of sand in mixtures with waste materials, relative to the reference mixture.

The flexural and compressive strength tests were performed at the mortar specimen age of 7, 28, and 90 days (Figures 1 and 2). Based on the test results, it can be observed that with the increasing cement replacement by waste material, the strength of mortar specimens decreased at an early age (7 days). On the other hand, with increasing age (28 and 90 days) the strength of mortar with the waste material approached the values of the reference mortar. This is attributed to the pozzolanic reaction of slag and silica fumes, which manifested itself at a later stage of hardening [17-20]. That is the reason that the percentage of possible replacement of cement with waste material was estimated based on strength at 90 days. The decrease in compressive strength was from $7.0 \%$ up to $19.2 \%$ with a percentage replacement of cement from $10 \%$ to $25 \%$. One of the reasons for the decrease in mechanical strengths is the lower density of mortar mixtures in which cement has been replaced by waste materials.

Replacement of cement with slag resulted in an increase in the value of water absorption at atmospheric pressure, while, on the other hand, it contributed to a decrease in the 
absorption coefficient due to capillary water absorption. However, regardless of the test method, the maximum difference in water absorption values was up to $15 \%$.

Based on the shrinkage measurements results due to the drying of cement mortars, (Figure 3), it can be observed that mortar mixtures with the addition of waste material had higher shrinkage values than the reference mortar, wherein the shrinkage was greater at a later curing stage. The reason for the increased shrinkage is the pozzolanic reaction of slag and silica fumes. Similar trends were observed by researchers for an examination of the influence of glass powder on the properties of cement mortar [19]. It should be mentioned that the highest shrinkage was recorded in the mortar mixture with $15 \%$ of cement replacement. This was likely because the porosities of the mortar mixtures, P20-M and P25-M, were higher than the porosity for P15-M, which means that these mixtures had a lower volume of the cement paste shrinking during hardening.

The replacement of cement with waste material had the effect of reducing the adhesion of the mortar to the concrete substrate. With an increase in the percentage of cement replacement, the adhesive strength decreased, with a decrease of 6-47\% (Figure 4). The possible reason for the reduction of adhesion in mortars with a higher content of waste material is the lower quantity of free water necessary for the hydration of cement materials in the hardening period.

Based on the results of concrete consistency testing, it can be concluded that as the content of waste material increased, the size of the slump decreased significantly. This was due to the porosity and higher specific surface area (Table 1) of the waste material and its ability to retain water, thereby reducing the amount of free water in the concrete mixture, and thus the consistency $[16,21,22]$. The content of air entrained into fresh concrete increased with an increasing percentage of cement replacement with waste material. By increasing the content of waste material, the bulk density of concrete in the fresh and hardened states decreased, as in the case of mortar mixtures. This can be ascribed to the higher content of entrained air in fresh concrete and the lower amount of aggregate in mixtures where a partial replacement of cement was performed, and to the lower specific gravity of waste materials in comparison with cement, Table 1.

The flexural strength test was performed at the ages of samples for 28 days (Figure 5). It can be noticed that the flexural strength decreased with the increase in the replacement of cement, and that was compared to the reference concrete in the range from 14 to $26 \%$. Compressive strength was the most significant characteristic of concrete, and it was determined at test specimen ages of 2, 7, 28, and 90 days (Figure 6). Firstly, it was observed that with the increase in cement replacement by waste material, the strengths of concrete specimens decreased at all ages of concrete. In the first 7 days, the highest increase in compressive strength was recorded with the reference mortar, while with increasing age the compressive strength of concrete prepared with waste material approached the reference concrete due to the delayed pozzolanic reaction [23]. The decrease in compressive strength at 90 days was $7.2-21.7 \%$ with a percentage replacement of cement of $10-25 \%$. The possible reason for the reduction of the final strength of concrete with the waste material is the lower density of concrete in comparison with the reference concrete due to the higher entrained air content and the lower amount of aggregate.

Generally, the replacement of cement with slag and silica fumes reduced the physical and mechanical properties of mortar and concrete, but cement composites retained the required structural properties. Mechanical strength, and especially compressive strength, were very important parameters for cement composites. If $15-20 \%$ was considered an acceptable level of compressive strength decrease, then it can be concluded that, in mortar and concrete production, cement could be replaced by waste material by up to $20 \%$. Additionally, results of the physical-mechanical characterization showed that mortar and concrete materials with $20 \%$ of cement replacement may be used as constructional materials in the construction industry. 


\subsection{X-Ray-Structural Diffraction Analysis (XRD) of the Mortar Samples}

Since the results of the testing of physical-mechanical properties showed that $20 \%$ was the maximal amount of cement which may be replaced by slag and silica fumes in mortar and concrete production, physical-chemical characterization was performed on the hardened mortar sample P20-M (containing cement (17.75\%), slag $(3.94 \%)$, silica fumes $(0.49 \%)$, river sand $(66.54 \%)$, water $(11.10 \%)$ and superplasticizer $(0.18 \%))$.

Results of the XRD analysis are shown in Figure 7.

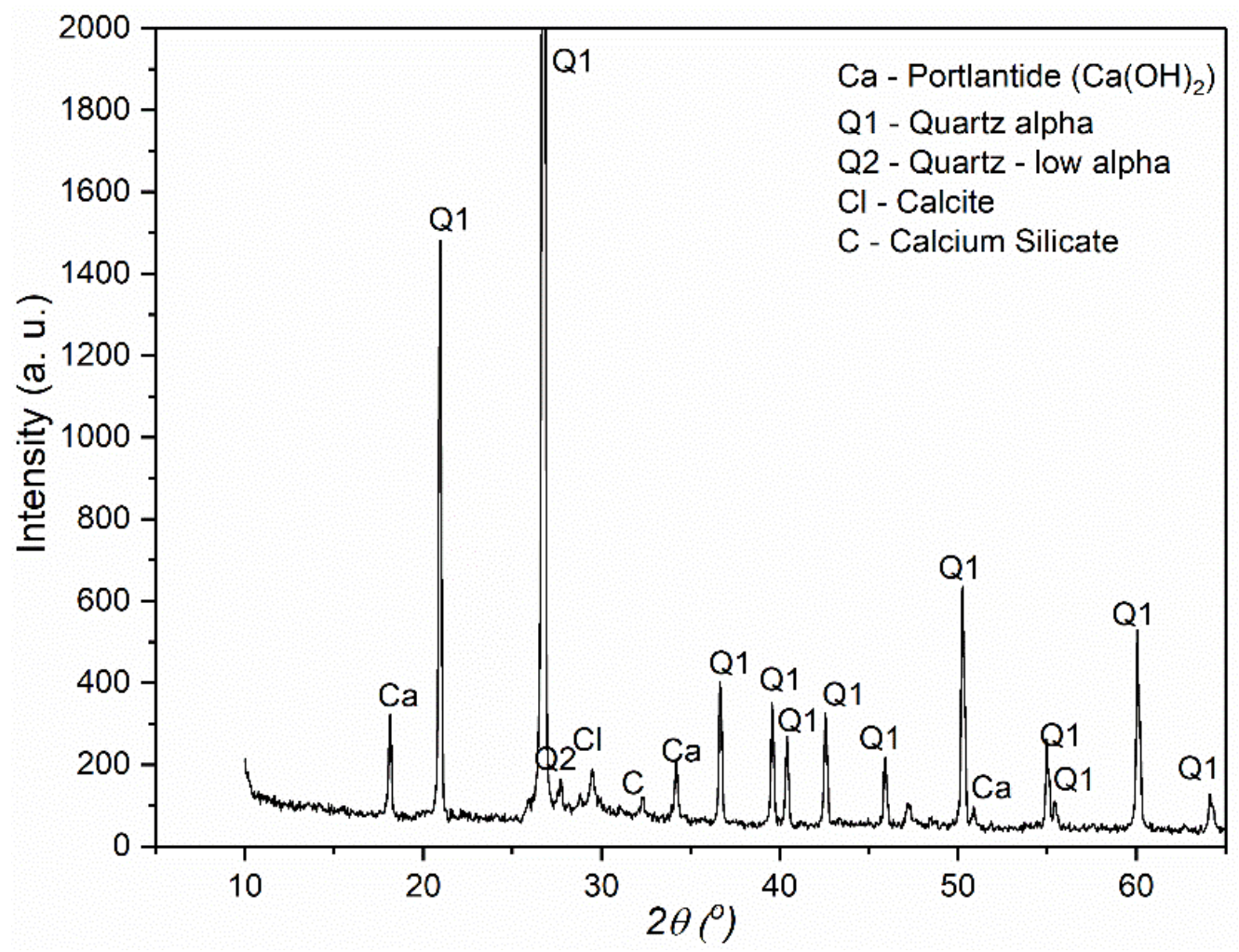

Figure 7. XRD analysis of the hardened mortar sample P20-M.

In the investigated sample the presence of the following crystal phases were observed: portlandite $\left(\mathrm{Ca}(\mathrm{OH})_{2}\right)$, quartz $\left(\mathrm{SiO}_{2}\right)$, calcite $\left(\mathrm{CaCO}_{3}\right)$, and calcium silicate-oxide $\left(\mathrm{Ca}_{2} \mathrm{SiO}_{4}\right)$. The most abundant phase was quartz, then portlandite, and calcite, while calcium silicateoxide was less present. Such composition was expected because portlandite, calcite and calcium silicate-oxide originated from cement, while quartz originated from river sand, silica fumes and slag. Other constituents of starting mortar components were not detected because their spectral bands overlapped with those originating from the most abundant crystalline phases. In the constituents from quartz, alpha-quartz is dominant. For hardened mortar, the crystallinity was high. Additionally, new crystalline phases except those which originated from starting samples were not detected by XRD. However, although this has not been determined in our research, the formation of new phases when waste material was used as a replacement or addition to cement was possible. For example, J. Seo et al. [24] showed that when blast furnace slag and calcium sulfoaluminate cement were mixed, a new phase strätlingite $\left(\mathrm{Ca}_{2} \mathrm{Al}_{2} \mathrm{SiO}_{7} \cdot 8 \mathrm{H}_{2} \mathrm{O}\right)$ was formed as a consequence of the reaction of aluminum-hydroxide and $\mathrm{Ca}_{2} \mathrm{SiO}_{4}$. The same phenomenon was also shown by other authors for steel slag [25] or ground perlite [26]. In order to definitively determine whether new phases had formed, additional methods of physical-chemical characterization were performed. 


\subsection{Infrared Spectroscopy with Fourier Transform (FTIR)}

The infrared spectrum of the hardened mortar is given at Figure 8. In the spectrum of the hardened mortar, spectral bands at 3337, 1464, 1434, 1124, 990, 874, 850, 692, 615, 520 , and $466 \mathrm{~cm}^{-1}$ are visible. The spectral band at $3337 \mathrm{~cm}^{-1}$ may be assigned to the $\mathrm{H}-\mathrm{H}$ stretching vibrations due to the presence of the physical-bounded and surface-adsorbed water [27]. The bands at 1464 and $1346 \mathrm{~cm}^{-1}$ are characteristic of and confirmed the presence of $\mathrm{Ca}(\mathrm{OH})_{2}$ [28]. The bands of 1434,874 , and $692 \mathrm{~cm}^{-1}$ are attributed to in- and out-plane bending and asymmetrical stretching vibrations of the $\mathrm{O}-\mathrm{C}-\mathrm{O}$, respectively, which occur due to the presence of the $\mathrm{CaCO}_{3}$ [29]. The bands at 1100, 797, and $615 \mathrm{~cm}^{-1}$ indicate the presence of the $\mathrm{SiO}_{2}$ and are characteristic of asymmetrical and symmetrical stretching modes $\left(1100,797 \mathrm{~cm}^{-1}\right)$ and bending mode $\left(615 \mathrm{~cm}^{-1}\right)$ as weak bands [30]. The spectral band at $466 \mathrm{~cm}^{-1}$ originates from $\mathrm{Fe}-\mathrm{O}$ vibrations due to presence of iron oxide (Table 1) [31,32].

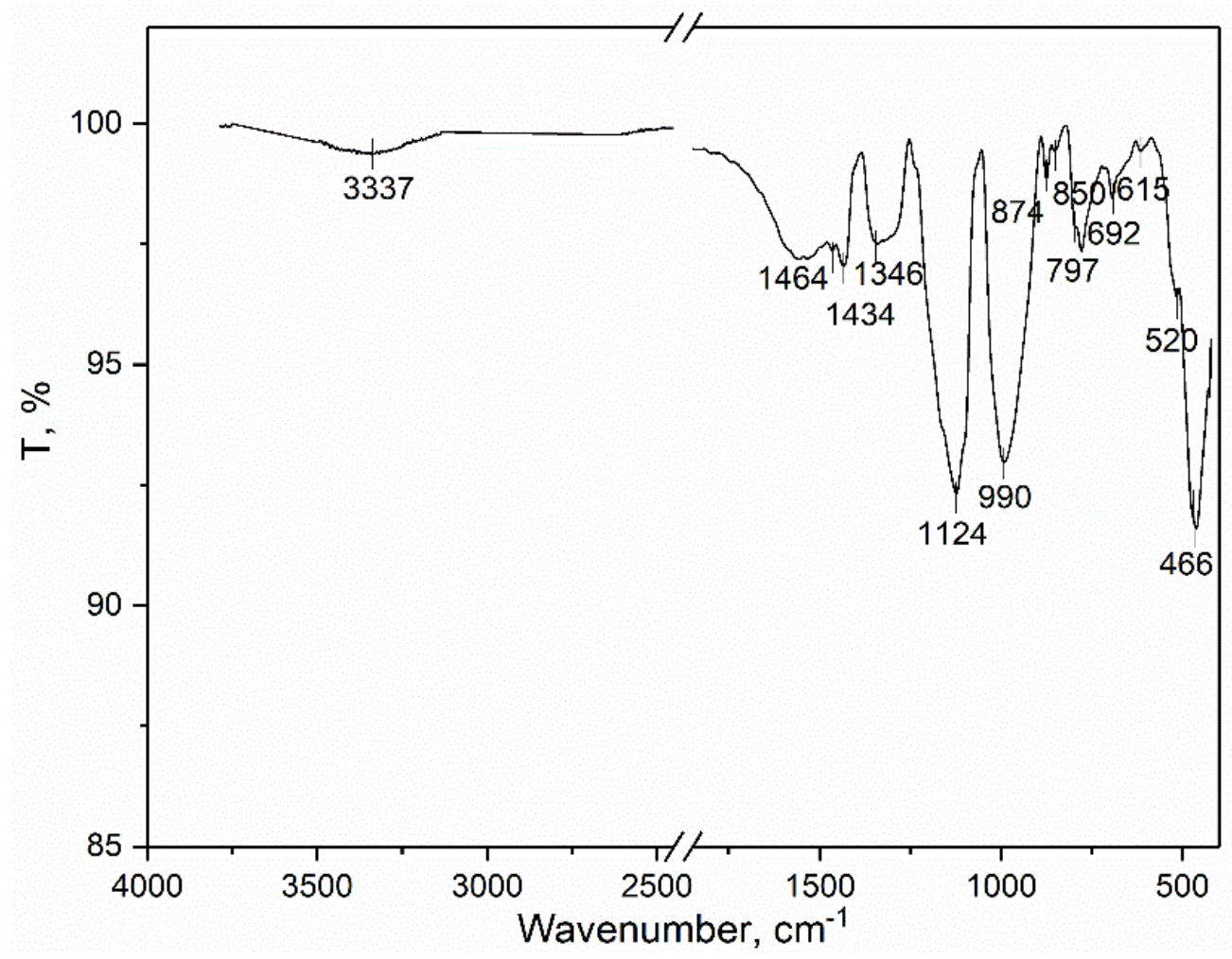

Figure 8. FTIR spectrum of the hardened mortar sample P20-M.

Other spectral bands at 990,850 , and $520 \mathrm{~cm}^{-1}$ are characteristic of the calcium silicateoxide $\left(\mathrm{Ca}_{2} \mathrm{SiO}_{4}\right)$ [33]. As it may be seen from the spectrum of the hardened mortar sample, only spectral bands of the main constituents detected by the XRD are visible. The spectral bands of the new functional groups, as well as bands of other constituents, are not visible which may be explained with overlapping spectral bands or what may be an indication that new phases are not formed.

\subsection{Scanning Electron Microscopy (SEM) of the Mortar Samples}

Results of the scanning electron microscopy (SEM) of the hardened mortar samples (P20-M) are given at Figure 9. 

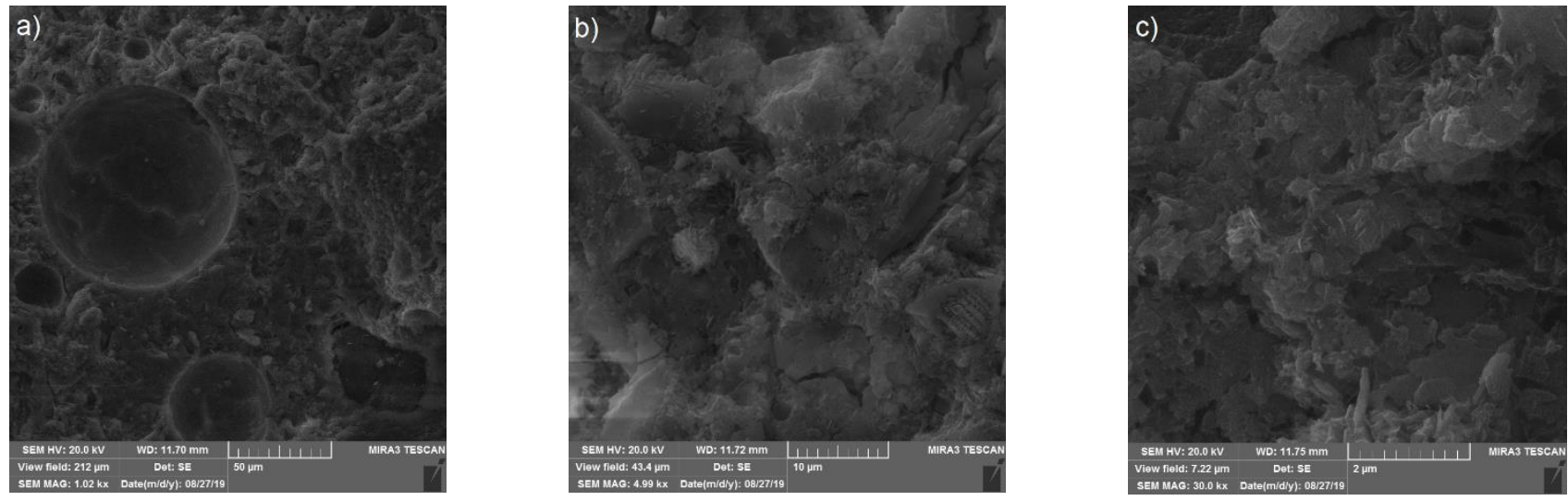

Figure 9. SEM micrographs of the hardened mortar sample P20-M taken with three different magnifications: (a) $1.02 \mathrm{k} \times$; (b) $4.99 \mathrm{k} \times$ and (c) $30.0 \mathrm{k} \times$.

The cementing matrix is a heterogeneous mixture of crystal phases that correspond to minerals in cement or other components in mortar. In a micrograph taken at a magnification of $1.02 \mathrm{k} \times$, ball-shaped, well-defined recesses are visible which are derived from water molecules that have been ejected from the surface by the preparation and hitting of the sample prior to analysis. The micrographs taken at higher magnifications (4.99 and $30.0 \mathrm{k} \times$ ) show a morphology in which shape and size of the platelets are characteristic of silicate, aluminosilicate and calcium hydroxide samples. The morphology shown by these investigations gives an indication that the applied design of the mortar production leads to the dispersion of cement, slag, silica fumes, river sand and superplasticizer.

\subsection{Thermal Analysis of the Hardened Mortar Samples}

Results of the thermal analyses (thermogravimetric and different thermal analysis (TGA-DTA)) of the designed hardened mortar sample with $20 \%$ of cement replacement are given in Figure 10.



Figure 10. Thermal analysis of the hardened mortar sample P20-M. - TGA; - DTA. 
From the results presented in Figure 10, it may be concluded that thermal analysis confirms the results of XRD and FTIR analysis and peaks characteristic of the phases present to the greatest extent are visible. As it may be seen from Figure 10, on the DTA curve of the investigated sample in the first temperature interval $\left(25-200^{\circ} \mathrm{C}\right)$, two endothermic peaks are visible, at 95 and $165^{\circ} \mathrm{C}$, of which the first one is associated with endothermic reactions such as the dehydration and removal of physically adsorbed water, while the second one originates from the dehydration and decomposition of the hydrates of the silicate-oxides, as well as calcium silicate-oxides [34]. This process has been followed with a weight loss of around $2.60 \%$ on the TGA curve. In the second temperature interval $\left(200-600{ }^{\circ} \mathrm{C}\right)$ endothermic peaks are observed at 373,460 , and $573{ }^{\circ} \mathrm{C}$. The peaks at $373{ }^{\circ} \mathrm{C}$ and $460{ }^{\circ} \mathrm{C}$ originate due to the decomposition of the calcium-hydroxide [34], while the existence of the endothermic peak at $573{ }^{\circ} \mathrm{C}$ confirms the presence of quartz (river sand) and or silicate fume $\left(\mathrm{SiO}_{2}\right)$ [35]. In this temperature interval $\left(200-600^{\circ} \mathrm{C}\right)$ determined mass loss by TG analysis was $3.11 \%$. Weight loss in the third temperature interval $\left(600-800^{\circ} \mathrm{C}\right)$ of $2.35 \%$ and the endothermic peak at $727^{\circ} \mathrm{C}$, is caused by the decomposition of the carbonates, which is additional confirmation of the presence of the calcite $\left(\mathrm{CaCO}_{3}\right)$ in the designed mortar [36].

\section{Conclusions}

The results presented in this study show that waste slag generated in a heating plant by the combustion of lignite and taken from the Valjevo landfill in Serbia, may, despite being hazardous waste, be used in combination with silica fumes as a partial replacement for cement in the production of mortar and concrete as materials in the construction industry. Results of the physical-mechanical characterization show that maximal possible cement replacement is $20 \%$ (17.8\% of slag and $2.2 \%$ of silica fumes) and for such a ratio, all requirements prescribed by the standards are satisfied.

Physical-chemical characterization is performed on the hardened mortar samples which have the maximal cement replacement (20\%).

The results of the XRD analysis show that the following crystal phases are present in the investigated sample: quartz as the most abundant, then portlandite and calcite, while calcium silicate-oxide is less present.

The results of the FTIR and thermal analyses confirm the results of the XRD analysis and only the spectral bands (FTIR) and peaks (TGA/DTA) of the main constituents detected by the XRD are visible, and indicate that new phases are not formed.

The results of SEM analysis indicate that the model of mortar production applied leads to the dispersion of cement, slag, silica fumes, river sand and superplasticizer.

Author Contributions: M.K. conceived and designed the experiments, wrote the paper, and contributed to all experiments and the analyzing of the obtained results; N.R. performed physicalmechanical measurements and contributed to analyzing the results; M.S., J.G. and I.R. participated in SEM and thermal analyses and analyzed the results; A.N. and S.P. contributed in XRD measurements. All authors have read and agreed to the published version of the manuscript.

Funding: This research received no external funding.

Data Availability Statement: The study do not report any data.

Acknowledgments: This work was supported by the Ministry of Education, Science and Technological Development of the Republic of Serbia through the realization of research themes 1702103 and 1702105 .

Conflicts of Interest: The authors declare no conflict of interest.

\section{References}

1. Zhang, F.; Xing, Y.; Chang, G.; Yang, Z.; Cao, Y.; Gui, X. Enhanced lignite flotation using interfacial nanobubbles based on temperature difference method. Fuel 2021, 293, 120313. [CrossRef]

2. Zhao, H.Y.; Li, Y.H.; Song, Q.; Liu, S.C.; Yan, J.; Ma, Q.X.; Zhu, X. Investigation on the thermal behavior characteristics and products composition of four pulverized coals: Its potential applications in coal cleaning. Int. J. Hydrogen Energy 2019, 44, 23620-23638. [CrossRef] 
3. Xia, W.C.; Xie, G.Y.; Peng, Y.L. Recent advances in beneficiation for low rank coals. Powder Technol. 2015, 277, 206-221. [CrossRef]

4. American Geosciences Institute. Available online: https://www.americangeosciences.org/critical-issues/faq/what-are-thedierent-types-of-coal (accessed on 30 May 2021).

5. Yu, J.L.; Tahmasebi, A.; Han, Y.N.; Yin, F.K.; Li, X.C. A review on water in low rank coals: The existence, interaction with coal structure and effects on coal utilization. Fuel Process Technol. 2013, 106, 9-20. [CrossRef]

6. Available online: https://iea.blob.core.windows.net/assets/c40f0317-f8e6-4f00-b183-27a24c7b6a8f/Coal_Information_2019 _Overview.pdf (accessed on 30 May 2021).

7. Aydin, S.; Baradan, B. Efect of pumice and fly ash incorporation on high temperature resistance of cement based mortars. Cem. Concr. Res. 2007, 37, 988-995. [CrossRef]

8. European List of Waste, the Classification of Waste Based on: The European List of Waste (Commission Decision 2000/532/ECConsolidated Version) and Annex III to Directive 2008/98/EC (Consolidated Version). Available online: http:/ / data.europa.eu/ eli/dec/2000/532/2015-06-01 (accessed on 25 May 2021).

9. Berryman, C.; Zhu, J.; Tadros, M. High-percentage replacement of cement with fly ash for reinforced concrete pipe. Cem. Concr. Res. 2005, 35, 1088-1091. [CrossRef]

10. Ray, T.; Mohanta, N.R.; Kumar, M.H.; Macharyulu, I.S.; Samantaray, S. Study of effect of temperature on behavior of alkali activated slag concrete. Mater. Today Proc. 2021, 43, 1352-1357. [CrossRef]

11. Czop, M.; Łaźniewska-Piekarczyk, B. Use of Slag from the Combustion of Solid Municipal Waste as a Partial Replacement of Cement in Mortar and Concrete. Materials 2020, 13, 1593. [CrossRef]

12. Rivera, J.F.; Cristelo, N.; Fernández-Jiménez, A.; de Gutiérrez, R.M. Synthesis of alkaline cements based on fly ash and metallurgic slag: Optimisation of the $\mathrm{SiO}_{2} / \mathrm{Al}_{2} \mathrm{O}_{3}$ and $\mathrm{Na}_{2} \mathrm{O} / \mathrm{SiO}_{2}$ molar ratios using the response surface methodology. Constr. Build. Mater. 2019, 213, 424-433. [CrossRef]

13. Zhang, Y.; Zhang, S.; Ni, W.; Yan, Q.; Gao, W.; Li, Y. Immobilisation of high-arsenic-containing tailings by using metallurgical slag-cementing materials. Chemosphere 2019, 223, 117-123. [CrossRef]

14. Tabelin, C.B.; Villacorte-Tabelin, M.; Park, I.; Phengsaart, T.; Jeon, S.; Hiroyoshi, N. Copper and critical metals production from porphyry ores and E-wastes: A review of resource availability, processing/recycling challenges, socio-environmental aspects, and sustainability issues. Resour. Conserv. Recycl. 2021, 170, 105610. [CrossRef]

15. Opiso, E.M.; Tabelin, C.B.; Maestre, C.V.; Aseniero, J.P.J.; Park, I.; Illacorte-Tabelin, M. Synthesis and characterization of coal fly ash and palm oil fuel ash modified artisanal and small-scale gold mine (ASGM) tailings based geopolymer using sugar mill lime sludge as Ca-based activator. Heliyon 2021, 7, e06654. [CrossRef]

16. Nedeljković, A.; Stojmenović, M.; Gulicovski, J.; Ristić, N.; Milićević, S.; Krstić, J.; Kragović, M. Waste Slag from Heating Plants as a Partial Replacement for Cement in Mortar and Concrete Production. Part I-Physical-Chemical and Physical-Mechanical Characterization of Slag. Minerals 2020, 10, 992.

17. Cheah, C.B.; Ramli, M. Mechanical strength, durability and drying shrinkage ofstructural mortar containing HCWA as partial replacement of cement. Constr. Build. Mater. 2012, 30, 320-329. [CrossRef]

18. Garcia, M.D.L.; Sousa-Coutinho, J. Strength and durability of cement with forest waste bottom ash. Constr. Build. Mater. 2013, 2013 41, 897-910. [CrossRef]

19. Grdić, D.; Ristić, N.; Topličić-Ćurčić, G.; Đorđević, D.; Krstić, N. Effects of addition of finely ground CRT glass on the properties of cement paste and mortar. Građevinar 2020, 72, 1-10.

20. Mafalda, A.; Sousa-Coutinho, J. Durability of mortar using waste glass powder as cement replacement. Constr. Build. Mater 2012, 36, 205-215.

21. Chavan, S.P.; Salokhe, S.A.; Nadagauda, P.A.; Patil, S.T.; Mane, K.M. An investigational study on properties of concrete produced with industrial waste red mud. Mater. Today Proc. 2021, 42, 733-738. [CrossRef]

22. Anirudh, M.; Rekha, K.S.; Venkatesh, C.; Nerella, R. Characterization of red mud based cement mortar; mechanical and microstructure studies. Mater. Today Proc. 2021, 43, 1587-1591. [CrossRef]

23. Sadiqul, I.G.M.; Rahman, M.H.; Kazi, N. Waste glass powder as partial replacement of cement for sustainable concrete practice. Int. J. Sustain. Built Environ. 2017, 6, 37-44.

24. Seo, J.; Kim, S.; Park, S.; Yoon, H.N.; Lee, H.K. Carbonation of calcium sulfoaluminate cement blended with blast furnace slag. Cem. Concr. Compos 2021, 118, 103918. [CrossRef]

25. Liao, Y.; Jiang, G.; Wang, K.; Al Qunaynah, S.; Yuan, W. Effect of steel slag on the hydration and strength development of calcium sulfoalumi-nate cement. Constr. Build. Mater. 2020, 265, 120301. [CrossRef]

26. Sengül, K.; Erdogan, S.T. Influence of ground perlite on the hydration and strength develop-ment of calcium aluminate cement mortars. Constr. Build. Mater. 2021, 266, 120943. [CrossRef]

27. Mojet, B.L.; Ebbesenz, S.D.; Lefferts, L. Light at the interface: The potential of attenuated total reflection infrared spectroscopy for understanding heterogeneous catalysis in water. Chem. Soc. Rev. 2010, 39, 4643-4655. [CrossRef] [PubMed]

28. Cavallaro, G.; Danilushkina, A.A.; Evtugyn, V.G.; Lazzara, G.; Milioto, S.; Parisi, F.; Rozhina, E.V.; Fakhrullin, R.F. Halloysite Nanotubes: Controlled Access and Release by Smart Gates. Nanomaterials 2017, 7, 199. [CrossRef] [PubMed]

29. Abdolmohammadi, S.; Siyamak, S.; Ibrahim, N.A.; Yunus, W.M.Z.W.; Rahman, M.Z.A.; Azizi, S.; Fatehi, A. Enhancement of Mechanical and Thermal Properties of Polycaprolactone/Chitosan Blend by Calcium Carbonate Nanoparticles. Int. J. Mol. Sci. 2012, 13, 4508-4522. [CrossRef] [PubMed] 
30. Tran, T.N.; Pham, T.V.A.; Le, M.L.P.; Nguyen, T.P.T.; Tran, V.M. Synthesis of amorphous silica and sulfonic acid functionalized silica used as reinforced phase for polymer electrolyte membrane. Adv. Nat. Sci. Nanosci. Nanotechnol. 2013, 4, 045007. [CrossRef]

31. Tabelin, C.B.; Veerawattananun, S.; Ito, M.; Hiroyoshi, N.; Igarashi, T. Pyrite oxidation in the presence of hematite and alumina: I. Batch leaching experiments and kinetic modeling calculations. Sci. Total Environ. 2017, 580, 687-698. [CrossRef]

32. Park, I.; Tabelin, C.B.; Magaribuchi, K.; Seno, K.; Ito, M.; Hiroyoshi, N. Suppression of the release of arsenic carriermicroencapsulation from arsenopyrite by using Ti-catechol complex. J. Hazard. Mater. 2018, 344, 322-332. [CrossRef]

33. Handke, M.; Ptak, W. IR and Raman studies of the stabilization beta-Ca2SiO4. Ceramurgia international 1978, 4, 75. [CrossRef]

34. Zhang, G.; Li, Z.; Zhang, L.; Shang, Y.; Wang, H. Experimental research on drying control condition with minimal effect on concrete strength. Constr. Build. Mater 2017, 135, 194-202. [CrossRef]

35. Schelz, J.P. The detection of quartz in clay minerals by differential thermal analysis. Thermochimicu Acta 1976, 15, 17-B. [CrossRef]

36. Parvan, M.-G.; Voicu, G.; Badanoiu, A.-I.; Nicoara, A.-I.; Vasile, E. $\mathrm{CO}_{2}$ Sequestration in the Production of Portland Cement Mortars with Calcium Carbonate Additions. Nanomaterials 2021, 11, 875. [CrossRef] [PubMed] 